\title{
Introduction: the need to discuss endogenous money again
}

\section{Louis-Philippe Rochon and Sergio Rossi}

The notions of credit and money, and how they interact with the real economy, have preoccupied heterodox economists for several decades, and even dominated the heterodox discourse for most of the 1980s and 1990s, with the so-called horizontalist-structuralist debates. However, we can trace the origins of the post-Keynesian theory of endogenous money to much earlier, to the work of Robinson (1956), Kaldor (1970), Moore (1979) and Eichner (1987) (see Rochon, 1999 and 2012 for a discussion). Indeed, while Kaldor and Moore are often associated with endogenous money, the same cannot be said for Robinson and Eichner, whose views on credit, money and banking are certainly more developed and richer than those of Kaldor and Moore.

In fact, the post-Keynesian theory of endogenous money would probably look very different today had post-Keynesians followed Robinson and Eichner early on. In the case of Robinson (1956), her views were certainly consistent with the modern circuit approach, and the notion of money as an institution related to the formation of debt. Eichner (1987) offers a degree of institutional detail, especially from the view of central banks, that has been absent in much of post-Keynesian theory, with the possible exception of Fullwiler (2003).

But what precisely is endogenous money? Anyone who has read some of the debates between horizontalists and structuralists would walk away with somewhat different interpretations. Does the central bank always accommodate banks' demand for central-bank money? Does it have the ability to increase the money supply exogenously? Can it really have the rate of interest of its choice? Has money always been endogenous or has it become endogenous through time with the advent of certain institutions?

These were just some of the questions that divided post-Keynesians for nearly two decades, and they warrant closer scrutiny, in particular in light of the financial crisis that erupted in 2007-2008. Have some of these questions been resolved by the sheer facts of experience? Has the crisis made more evident how central banks behave, one way or the other? 
What is clear is that at the heart of the theory of endogenous money lies a two-fold relationship between commercial banks and banks' borrowers, on the one hand, and between commercial banks and the central bank, on the other, or what Monvoisin (2006) has called the 'two poles of money's endogeneity'. While the first relationship largely preoccupied proponents of the monetary circuit approach, under its various incarnations, the second was the essence of the debates among post-Keynesians.

Quite naturally, a dialogue between circuitists and post-Keynesians seemed appropriate since each was discussing a different side of the same coin, which was the motivation behind Deleplace and Nell's (1996) volume, in which post-Keynesians and circuitists debated the nature of money but also the mechanics of central banking. While post-Keynesians and circuitists often disagreed on many details, they largely agreed with the rejection of the savings-investment causality, and the need to finance production through the supply of bank credit.

Whether the differences among the various protagonists were a matter of substance or degree remains a question unanswered today. As Moore (2001, p. 13) has claimed, it might have been a 'storm in a teacup'. We disagree.

As a matter of fact, there were some fundamental differences regarding the nature of reserves (or settlement balances) that are still far too evident today. Indeed, the debate over quantitative easing and negative interest rates shows a fundamental difference on how we see the role reserves play in the economic system. For instance, horizontalists (see Moore, 1988; Lavoie, 1992; Rochon, 1999) have always argued that reserves are fully endogenous and carry no causal role in the determination of bank credit. Yet, Palley (1996) and Pollin (1996) have argued that there is a bi-causal role: while deposits create reserves, reserves in turn determine loans. Rochon (1999) argued that this was essentially the money-multiplier model of neoclassical theory at play.

This fundamental misunderstanding regarding the proper role of reserves arose recently once again, with both Palley (2010) and Pollin (2010) arguing that the accumulation of reserves at the central bank following quantitative easing is the result of interest being paid on reserves (IOR), with the assumption that banks could lend reserves if properly motivated. In this sense, Pollin and Palley support the policy of negative interest rates: impose a sufficiently unattractive tax on reserves and banks will be willing to lend out their excess reserves. Yet, once again, this is attributing to reserves a causal role in the determination of bank loans, and is nothing more than the money-multiplier model and heavily influenced from a neoclassical perception of bank lending and of banking institutions. 
Despite these distractions, we believe that over the last 15 years or so, through the events of our times, there has been considerable convergence among post-Keynesians to the point that we can now say that we are all horizontalists, in the sense that it is now evident that central banks do indeed control the rate of interest and let the supply of 'high-powered money' adjust to the needs of the economic system. The failure of quantitative easing and the (eventual) failure of negative interest rates will clearly show the passive role of bank reserves, and their actual use in interbank settlement (see Rossi, 2007).

Indeed, a proper post-Keynesian analysis emphasizes the endogenous nature of reserves; as such they cannot be causal in the bank lending story. In other words, banks do not lend reserves. Introducing negative rates of interest will do nothing in terms of encouraging banks to supply more loans. As explained by many post-Keynesians (see Lavoie, 1992; 2014; Rochon, 1999), banks are only constrained by the availability of creditworthy borrowers, not by the lack of liquidity. As Eichner (1987, p. 854) wrote,

[b]anks are not inclined to approve bank loan applications just because they have excess reserves. They will, in fact, be willing to grant loans only to those who can demonstrate that they are 'credit-worthy'. And once this demand for loans has been satisfied, no additional credit is likely to be extended.

What this shows, therefore, is that a proper understanding of money is still required, and that a careful observation of the institutional actions of central banks would reveal how recent so-called unconventional policies are doomed to fail. Revisiting the fundamental elements of the theory of endogenous money would result in a different set of monetary policy recommendations.

\section{RECENT ADVANCES IN ENDOGENOUS MONEY}

Since these crucial beginnings, post-Keynesian economists have developed and refined their theory of endogenous money, but not without conflict and controversy, both internal and external. Nevertheless, endogenous money remains the cornerstone of the post-Keynesian approach to the theory of output, employment and economic growth. Yet, since the early 2000s, post-Keynesians have largely moved on, perhaps owing to a general sense of fatigue following some rather intense exchanges.

However, even though endogenous money is a central element of postKeynesian economics, it is hardly a feature unique to post-Keynesian 
authors. Indeed, Smithin (1994) points out that endogenous money is not a sufficient argument to distinguish post-Keynesian theory from other approaches, in particular from some more orthodox traditions. To be sure, some form of endogenized ${ }^{1}$ money can be found in Wicksell (1898 [1965]) or in 'new consensus' models. As Lavoie (1996, p. 533) argues, endogenized money can even be found in the monetarist tradition, albeit in an openeconomy setting with fixed exchange rates. The presence of endogenized money in mainstream models, however, is subject to some important caveats, such as what is meant exactly by 'endogenous' or 'endogenized' money.

Regardless of this debate, two important features distinguish these mainstream versions of endogenized money from the view defended by post-Keynesian authors (and other heterodox economists). First, postKeynesians reject the existence of a natural rate of interest, and emphasize the strong connection between money and production, on the one hand, and between money and debt, on the other. Second, there remain deep and irreconcilable differences with respect to both the explanation of inflation and the role played by monetary policy. ${ }^{2}$

Regarding the natural rate of interest, Wicksell (1898 [1965], p. 102) argues that ' $[t]$ here is a certain rate of interest on loans which is neutral in respect to commodity prices, and tends neither to raise nor to lower them'. This rate is determined by the forces of productivity and thrift, and as such can be defined as a real rate of interest. At this rate, real GDP is equal to potential GDP, absent any transitory shocks to demand. Underpinning Wicksell's claim, of course, is a neoclassical general-equilibrium framework in which profit is portrayed as a real return to the productivity of invested capital. In theory, this rate is unique, in the sense that the economy would be in equilibrium only at this rate.

One crucial problem, of course, is that this natural rate of interest is neither observed nor calculable, although this has not diminished central bankers' fondness in referring to this rate in developing their policies, conventional or otherwise. It is in this sense that Rochon (2016) argues that the belief in natural rates is akin to the pursuit of the Holy Grail: central bankers believe in its existence even in the absence of proof. For instance, in new-consensus models, the purpose of policy is to adjust the nominal (or real) rate of interest according to an inflation and output gap, in the hope that it will eventually equate to the natural rate of interest. In fact, 'the mainstream's continued reliance on the assumed existence of a natural rate of interest has fundamentally shaped the so-called unconventional policies implemented since 2008-2009' (ibid., p. 87).

Post-Keynesians reject the existence of a natural rate of interest (Rogers, 1989; Smithin, 1994; Lavoie, 2014) for two important reasons. First, 
post-Keynesians see the rate of interest as a purely exogenous (and distributive) variable. Second, full employment can be achieved at any interest rate: there is no unique rate of interest around which the economy gravitates.

With respect to inflation, the mainstream and post-Keynesian approaches still see the inflation process as very different from each other. In the mainstream view, inflation was once considered the result of excess money, that is, as a monetary phenomenon. The causality would run from the central bank's decision to increase the money supply exogenously to the price level: any excess supply of money would translate into an increase in the price level. Changing the emphasis from control over the money supply to control of the interest rate, as in recent New Keynesian models, changes this story very little, or even not at all. Indeed, the causality is still explained in terms of a central bank's decision to change monetary policy: a change in the rate of interest will still lead to a change in aggregate demand, which will impact the price level. The transmission mechanism is similar. Hence, inflation is still seen as the result of excess aggregate demand. In this sense, we could say that, in mainstream models, inflation is 'always and everywhere a monetary policy phenomenon' (Rochon, 2016, p. 94).

By contrast, post-Keynesian economists minimize the role played by excess demand in explaining inflation. In the post-Keynesian approach, inflation is the result of supply factors (cost-push inflation), notably resulting from a conflict between workers, firms and rentiers over the appropriate share of their respective income. The rate of interest in this approach is considered as a distributive variable (see Eichner, 1987; Rogers, 1989; Lavoie, 2014). ${ }^{3}$ This raises important questions regarding the proper role attributed to monetary policy, and the income distributive nature of interest rates has specific implications. First, this suggests that the transmission mechanism of monetary policy should be reconsidered. In particular, it suggests that monetary policy impacts aggregate demand through income distribution. This leads to our second observation: if this is correct, then the use of counter-cyclical policies, or fine-tuning, by the central bank becomes inefficient. Indeed, aggregate demand may not be sensitive to changes in the rate on interest, which makes fine-tuning an inappropriate use of interest rates.

The above discussion has led Lavoie (1996, p.536) to argue that 'monetary policy should not so much be designed to control the level of activity, but rather to find the level of interest rates that will be proper for the economy from a distribution point of view'.

Furthermore, if orthodox approaches to endogenized money appear to be similar to the post-Keynesian theory on the surface, they are rooted in 
quite different theoretical frames of analysis, and nothing indicates that the mainstream has peered over the ledge of the exogeneity of the rate of interest to consider the true nature of money. In fact, beyond the rate of interest, there does not appear to be much difference between this version of mainstream monetary theory and the old version of it, prompting Lavoie (2006, p. 167) to refer to it as 'old wine in a new bottle'. According to Palley $(2006$, p. 80$)$, the new consensus 'is a conception of [money's] endogeneity that is fundamentally different from the Post-Keynesian conception, which is rooted in the credit nature of money'. He calls the new-consensus approach 'central bank endogeneity', echoing similar arguments put forth by Rochon (1999) regarding the distinction between what the latter called the 'evolutionary' and 'revolutionary' endogeneity of money (see also Rochon and Rossi, 2013).

Now, whilst post-Keynesian economists reject the existence of a natural rate of interest and share a common view of inflation, this does not mean that there is consensus on the rest of the intricacies regarding the endogeneity of money. Indeed, scholars and students of heterodox monetary economics are quite familiar with the debates between the socalled 'structuralists' and 'horizontalists' regarding the role of the central bank and the specific relationship between the central bank and commercial banks with respect to 'high-powered' reserves, as discussed above.

Regardless, there can be no doubt that endogenous money is one of the fundamental characteristics of post-Keynesian analysis. It anchors postKeynesianism in a long tradition of monetary analysis, and emphasizes the important link between credit and production, and the role of central banks in maintaining the liquidity of the overall system. It is, in a way, the starting point of many discussions regarding production, economic growth and income distribution.

\section{THE HORIZONTALIST AND STRUCTURALIST DEBATES REVISITED}

Nevertheless, and probably more than any other issue, the endogenous nature of money has generated a great deal of debate and controversy within post-Keynesian economics, as argued above. Many would argue that these debates inflicted considerable harm on post-Keynesian economics, as they unnecessarily distracted from doing positive, constructive research. While this may not be completely inaccurate, these debates nonetheless served an important purpose. First, even at the time of writing, they remain a great curiosity among graduate students interested in monetary theory and policy all over the world, and doctoral dissertations are still being 
written on that topic, offering novel insights. Second, they have allowed post-Keynesian economists to deepen their understanding of institutions and central banks in particular. In fact, some (see Fullwiler, 2003, and this volume; Panagopoulos and Spiliotis, this volume) now present us with detailed analysis of central-bank operations, fully consistent with the endogenous-money view.

Despite these positive elements, some confusion has remained. One of the most confusing aspects of this debate, ironically, has been the precise definition of endogeneity. Indeed, it was not always clear what money endogeneity exactly meant. In fact, this expression has been employed in different ways and with different meanings. While horizontalists were arguing in terms of the endogeneity of credit money, structuralists were arguing in terms of central-bank money. Horizontalists were thereby claiming that money is always endogenous, as it depends on the debt relationship between banks and bank borrowers: since banks are always willing to grant credit to creditworthy borrowers, money is endogenous irrespective of the historical period or the state of financial innovations. This view was also shared by proponents of the monetary circuit (see Deleplace and Nell, 1996, for a summary). This argument was well summarized by Lavoie (1996, p.533, italics in the original), who argued that 'endogeneity is not a matter of institutions but rather one of logical necessity'. In other words, money is always endogenous regardless of the specific institutional arrangements. According to Lavoie (1996, p. 533), 'accommodation or the lack of it, liability management or the lack of it, and financial innovation or the lack of it are second-order phenomena compared to the crucial causal story that goes from debt creation to the supply of means of payment'. Hence, it does not matter whether central banks accommodate or not banks' needs for central-bank money: money is naturally endogenous, since it is the result of a sequence of logical events involving a debt relationship between banks and borrowers. This is the position taken by Rochon and Rossi (2013, and this volume), as well as by advocates of the theory of the monetary circuit (see, for instance, Graziani, 2003).

Structuralists, on the other hand, associated endogenous money with central-bank operations only. In this sense, they shifted the argument away from credit money and the nature of money as debt, to focus on central-bank money. Accordingly, money is endogenous only when the central bank accommodates the needs of commercial banks. When central banks refuse to accommodate these needs, money remains exogenous (this is what Rochon and Rossi, 2013, have labelled the evolutionary view of money; see Chick, 1986 and Niggle, 1991, for an espousal of that view). Minsky (1982), Palley (1996) and Pollin (1996) have argued that money is both endogenous and exogenous. 
In essence, both horizontalists and structuralists argued at opposite ends of the endogeneity spectrum: the relationship between banks and their borrowers, at the one end, and the relationship between banks and the central bank, at the other. In fact, according to Monvoisin (2006), money's endogeneity must encompass discussions of both elements. In the end, both horizontalists and structuralists really boil down to a similar argument: whether one is discussing credit money or central-bank money, it is the supply of each that responds to the demand for it. Horizontalists and structuralists are therefore simply discussing different issues of the same argument. Hence, horizontalists and structuralists are largely in agreement with the notion that both credit money and central-bank money are endogenous, the main difference between the two approaches being the degree to which these two forms of money are endogenous. Indeed, horizontalists argued that in both cases the supply of money is fully endogenous, while structuralists argued that the money supply is not always completely endogenous, which gives rise to important consequences in the real world.

\section{STRUCTURE OF THE BOOK}

This volume gathers a series of contributions on the analysis of endogenous money; that is, the fact that money is issued as a result of a demand for credit addressed to any kinds of banks, on top of which there is a central bank operating as a settlement institution on the interbank market. Endogenous-money analysis is a feature of heterodox economics, particularly of post-Keynesian economics, because orthodox economic analysis either neglects or ignores the fact that banks issue money independently of the policy stance of monetary authorities. The mainstream view in this regard is still captured by the money-multiplier image, according to which any central bank is always and everywhere in a position to increase or reduce the money supply via either a quantitytheory-of-money channel or an interest-rate channel: the former would operate directly from base ('high-powered') money to the total money supply, whilst the latter would operate indirectly, from the policy rate of interest to the volume of credit provided by banks, as a result of which the money supply is affected according to the central bank's objectives. In the real world, however, the emission of money cannot be determined or controlled by the central bank, because it stems from the payment order that the payer sends to the paying bank, where the result of this payment is recorded in the form of a bank deposit (see Rossi, 2007). This mechanics of money's emission is unavoidable and does not depend on 
agents' behaviour, although the latter impacts on the total volume of bank deposits in any given period of time.

Part I of this volume expands and elaborates on this debate, referring to both ancient and modern times across the world. Chapter 1, contributed by Jane Knodell, provides several examples of money's endogeneity in ancient history, before central banks were actually set up. Knodell examines in particular two early monetary systems that lacked central banks, that is, metallic money in western Europe during the fifteenth, sixteenth and seventeenth centuries, and paper money in eighteenth-century Britain and British North America. She finds these systems to have been imperfectly endogenous, owing to the inadequacies in their mechanics of money supply. Further, Knodell argues that money's endogeneity did not evolve in an unremittingly forward path historically, as the relevant literature suggests: the author points out that, in some respects, metallic-money systems were more flexible than paper-money systems.

Now, while neoclassical economists have focused on monetary policy strategies and largely neglected the details of their implementation, a growing body of empirical research - particularly from those economists currently or previously associated with central banks - since the late 1990s has investigated these details even if they have not yet made their way into standard models. By contrast, the post-Keynesian tradition has incorporated monetary policy implementation for several decades as a core part of its critique of neoclassical models. Even within this tradition, though, there are significant differences between horizontalists and structuralists. Chapter 2, written by Scott Fullwiler, focuses on ten principles underlying central-bank operations in general that one might consider to be 'what every economist should know' about this subject matter. Many, if not most, of these principles are contrary to the standard neoclassical models and textbooks, and, with regard to the post-Keynesian literature, tend to favour the horizontalists' view over the structuralists' view.

In Chapter 3, Thomas Palley sets out from the fact that money must be at the centre of any macroeconomic analysis, which makes understanding the money supply central for macroeconomic theory. This chapter presents the post-Keynesian theory of endogenous-money supply and shows that it is fundamentally different from conventional money-supply theory. The conventional approach relies on the money multiplier and bank lending is invisible. Post-Keynesian theory discards the money multiplier and focuses on bank lending, which drives money creation. In his chapter, Palley emphasizes the structuralist version of the post-Keynesian theory of endogenous money, which retains Keynes's liquidity preference theory of long-term interest rates, and also considers that banks are subject to 
financial constraints that limit their lending activities. Palley then shows how to derive the LM schedule in an endogenous-money economy, which is a necessary prelude to reconstructing the IS-LM model.

In Chapter 4, Sergio Rossi argues that the academic debate between horizontalists and structuralists was misplaced, as both camps are right as well as wrong in their analyses and conclusions. Rather than being 'a storm in a teacup', as Moore (2001, p. 13) puts it, this debate assimilated what ought to be kept distinct, and to some extent distinguished what should be seen 'as a whole'. This chapter aims at clarifying some points that are the backbone of that debate, in order to clear the air after the 'storm' that has done more harm than good to the construction of a rigorous alternative to orthodox monetary thinking - which is flawed on its own grounds as Rossi (2001, ch. 4) shows, referring to the nature of money. In the present chapter, Rossi first draws a clear-cut distinction between money and bank deposits in order to set the record straight as regards the working of a single-bank system. He then elaborates on the role of the central bank in a multi-bank system, to show that even central-bank money is always and everywhere an endogenous phenomenon, owing to the need of a means of final payment on the interbank market. On these grounds, he further explains a central bank's interest-rate determination referring to the Canadian case, which is a very efficient system for interest-rate control within a complex payment system, in which the general government sector is an important agent.

The aim of Chapter 5, contributed by Yannis Panagopoulos and Aristotelis Spiliotis, is to extend the debate between horizontalists and structuralists over the money-supply process, taking into consideration the restrictions that emerged in the Basel III framework. The authors propose a two-step approach: first, they examine the existence of a new 'equity credit multiplier', that is, the importance of banks' equity in their lending process. Then, as an extension to the first step, they embed this 'equity effect' into an original multivariate loan model. Furthermore, the authors apply this two-step approach on empirical grounds in the euro area for the period 1998-2014. Their conclusion is thus two-fold: first, there is a strong empirical indication of money endogeneity in the system with a reversed 'equity credit multiplier'; second, according to their multivariate loan model, there is a 'redefined' structuralism in the current banking system.

Chapter 6, written by Noemi Levy-Orlik, focuses on liquidity, finance and economic growth in emerging market economies. The assumption that money can disturb economic activity has reached consensus across different schools of economic thought, but there remain differences in terms of the channels through which this effect occurs. A wide acceptance has reached the assertion that central banks can only set their policy rate of interest and are unable to control the money supply, so that debt 
originates money, which has become structurally endogenous. In this framework, the author then analyses the different heterodox interpretations of money's endogeneity, highlighting the discussion on money's creation and destruction and how it applies to developing economies, where demand for investment expenditure is limited and exchange rates have become increasingly important. Levy-Orlik focuses her analysis on the Mexican economy during the period 1980-2007, just before the second financial crisis occurred in that country.

Part II of this volume presents a series of contributions regarding endogenous money in the history of economic thought. Chapter 7, written by Allin Cottrell, examines whether it is right to consider the case of commodity money using the quantity theory of money. Cottrel considers two questions in this regard: (i) What is the correct analysis of the case of commodity money? (ii) What did the classical monetary theorists have to say on this subject matter? The author concludes that these two questions are not separable: in seeking an adequate analysis of commodity money, one is indeed obliged to engage with those writers who have had the most to say on the matter.

In Chapter 8, John E. King begins by asking what, for Nicholas Kaldor, is wrong with the quantity theory of money. He thereby considers the related question of what can be expected, and cannot be expected, from monetary policy. This leads him to discuss Kaldor's views on the alternatives to monetary policy, which do display a remarkable consistency from the mid 1930s right through to the mid 1980s. King concludes his chapter by asking what Kaldor would have made, in the second decade of the twenty-first century, of the so-called 'new consensus' in macroeconomics, and especially in macroeconomic policy.

Colin Rogers, the author of Chapter 9, focuses instead on Keynes's principle of effective demand, pointing out that Keynesian economists of all shades have failed to incorporate the theoretical implications of that principle (Keynes, 1936). In his chapter, Rogers provides a definition of the principle of effective demand that is consistent with The General Theory and applies it to illustrate Keynes's (ibid.) claim for the existence of long-period unemployment equilibrium and as the basis for his policy proposals. The author then applies the principle of effective demand to illustrate that, although some post-Keynesian models incorporate the endogeneity and non-neutrality of money, these models do not capture the properties of the principle of effective demand, particularly the distinction between the rate of interest and the marginal efficiency of capital. Hence such post-Keynesian models, like many New Keynesian models, allow for the complete crowding-out of fiscal policy, contrary to Keynes's General Theory. Rogers argues that incorporating the distinction between the rate 
of interest and the marginal efficiency of capital into a post-Keynesian model eliminates complete crowding-out and supports Keynes's policy proposals. From this perspective, the endogeneity of money is thus an implication of Keynes's proposal to gain control of the rate of interest by nationalizing the Bank of England, which in turn follows from the principle of effective demand.

Chapter 10, contributed by Malcolm Sawyer, focuses on endogenous money from what the author calls 'the tyranny of demand and supply'. According to him, the terminology of demand and supply is highly misleading in the context of money and both terms have been applied in quite inappropriate ways. The attention paid to the money-supply curve in the horizontalist and structuralist debates has distracted from the analysis of the key elements of endogenous money, including how money is issued and destroyed. Furthermore, Sawyer argues that any observed relationship between interest rates and the volume of loans and of money does not represent a supply-of-loans relationship, and that a search for some general relationship between the volume of loans and the rate of interest is misplaced. From this perspective, Sawyer argues for trying to expunge the terminology of demand and supply from the debates on endogenous money, and to forego the search for a well-defined relationship between the rate of interest and the volume of loans and of money in existence.

In Chapter 11, Christopher J. Niggle investigates the role of endogenous-money theory in the development of evolutionary postKeynesian macroeconomics, in which money and the process of money creation are both analysed as evolving institutions. Niggle discusses the revival of endogenous-money theory as part of the post-Keynesian critique of both monetarism and the neoclassical-synthesis version of Keynesianism - what Joan Robinson (1962, p.690) dubbed 'bastard Keynesianism'. The author further discusses some controversies and debates within evolutionary post-Keynesian literature, including the horizontalist-structuralist debates, before considering the institutions that influence the degree of money-supply endogeneity. Niggle also assesses the role of endogenous money within current macroeconomics.

Chapter 12, written by John Smithin, examines interest-rate determination with the endogenous-money approach. As the author points out, the debate, near the end of the twentieth century, between horizontalists and structuralists was about the need to reconcile the notions of endogenous money, central-bank interest-rate operating procedures, and the intuitive idea, from Keynes, that liquidity preference also matters for the determination of interest rates. In fact, all of these things are entirely compatible according to Smithin. However, he argues that it is important to move beyond the strict terms of reference of the twentieth-century 
debate, to recognize that the most important point at issue is about the determination of real interest rates, not just nominal interest rates. If the central bank can target the real policy rate of interest, then it will certainly also have much influence over the real interest rates actually paid by any borrowers, including firms making investments. According to Smithin, however, it is by no means a contradiction to suggest that liquiditypreference considerations can also separately influence the effective real rate of interest.

Part III, the last part of this volume, expands on this, presenting a series of contributions to the most recent debate within post-Keynesian economics regarding money's endogeneity. Chapter 13, contributed by Peter Docherty, focuses on the analytical role of money's endogeneity in the horizontalist-structuralist debate. This chapter argues that locating the main points at issue in that debate within a well-articulated framework that takes careful account of the analytical role of endogenous money highlights the potential for greater complementarity of and consistency between the two perspectives. The author outlines an essentially horizontalist theory of long-run unemployment, but shows how key dimensions of structuralism are consistent with this theory on a number of points.

In Chapter 14, Paul Dalziel draws some lessons from the empirical evidence provided by New Zealand with regard to the horizontaliststructuralist debate about endogenous money. Indeed, New Zealand was the first country in modern times to adopt a formal inflation target, introduced as part of its monetary disinflationary programme in the late 1980s. The author sets off by providing an outline of the monetary policy debates in New Zealand, focusing on New Zealand's monetary disinflation from 1986 to 1993 . He then explains how post-Keynesian theories provided insights into several important features of that episode. Dalziel further draws on a particular horizontalist controversy about the validity of the Keynesian multiplier, to defend the post-Keynesian claim that monetary policy is not neutral in the long run. He thereby describes the most controversial of his contributions to the horizontalist view, which argues that the banking system is able to create an excess supply of credit money to generate inflation. This contribution eventually shows how postKeynesian monetary analysis remains highly relevant for current policy debates.

The fact that the rate of interest is a macroeconomic distribution variable features also in Chapter 15, written by Eckhard Hein, who reviews the main arguments put forward against the horizontalist view of endogenous money and an exogenous rate of interest under the control of monetary policies. Hein argues that the structuralist arguments put forward in favour of an endogenously increasing interest rate when investment and economic 
activity are rising, owing to increasing indebtedness of the firms sector or decreasing liquidity in the banking sector, raise major doubts from a macroeconomic perspective. Hein supports this argument by examining the effect of increasing capital accumulation on the debt-capital ratio of the business sector in a Kaleckian distribution and growth model. In particular he shows that rising (falling) capital accumulation may be associated with a falling (rising) debt-capital ratio for the economy as a whole and hence with the 'paradox of debt'. Therefore, the treatment of the rate of interest as an exogenous macroeconomic distribution parameter in post-Keynesian distribution and growth models is well founded according to Hein.

Chapter 16, authored by Marc Lavoie, assesses the structuralists' perspective using a coherent stock-flow framework. This accounting framework provides a general fully coherent tool, which takes into consideration the various interdependences that link income flows to changes in financial assets. This is important because, as explained by Lavoie in this chapter, several debates around the issue of endogenous money arose as a consequence of the lack of such a general all-round model. His chapter sets off from the principles of the stock-flow framework, then illustrates this framework with a simple economic growth model without government debt but with private money. Lavoie then discusses some results achieved by running simulations with this accounting model, to explain the controversies that have arisen around Minsky's (1982) financial fragility hypothesis.

In Chapter 17, Louis-Philippe Rochon and Sergio Rossi explore a remaining point of debate among post-Keynesians, that is, the historical account of money's endogeneity. The authors want to know if money has always been endogenous, or whether its endogeneity is the result of recent events and, in particular, of the evolution of the monetary and financial system. Within post-Keynesian literature, the authors identify two approaches to this question, which they label the 'evolutionary' and 'revolutionary' views respectively. To some extent, these approaches overlap with the 'structuralist' and 'horizontalist' stance respectively. The authors begin by discussing the so-called evolutionary view of endogenous money, as argued by Chick's (1986) theory of the evolution of the banking system. In its stead they propose what they call a revolutionary (see Rochon, 1999) definition of endogenous money consistent with many aspects of post-Keynesian economics as well as with the monetary circuit approach, where the money-creation process is always and everywhere an endogenous phenomenon, irrespective of the historical period. This alternative analytical view rests on the nature of debt, the role of settlement institutions, and the functional link between production, money and 
income. In this regard, the historical evolution of the banking system has made plain what has always been the case in reality, to wit, the endogenous nature of money emissions.

Mark Setterfield, in Chapter 18, elaborates on this, considering the shape of the credit-supply curve in quantity of credit-interest-rate space. This chapter views the resulting debate between horizontalism and structuralism through the lens of the 'history versus equilibrium' distinction in post-Keynesian macrodynamics. The argument is that there can be, and to an extent already is, agreement that the horizontal credit-supply curve is not a special case, and that the existence of an indeterminate dynamic credit-supply schedule provides a general framework capable of accommodating both horizontalist and structuralist arguments. Setterfield shows that these claims rest on the distinction between logical and historical time and, in particular, on the claim that any construct (including, for example, a credit-supply schedule) that is akin to a determinate long-run equilibrium relationship is indeed anathema to the methodological foundations of post-Keynesian economics.

In Chapter 19, the last chapter of this volume, Giuseppe Fontana argues that both horizontalist and structuralist analyses of endogenous money provide insightful perspectives on the way central banks, commercial banks, firms, financial intermediaries and wage-earners enter into the money-supply process. As Fontana shows, these perspectives are still presented in a dualistic style, with readers asked to be supporters of either horizontalism or structuralism. The graphical analysis proposed in Chapter 19 goes beyond this dualistic view of endogenous money, by presenting in a concise way the nature and origin of the differences between horizontalists and structuralists. This chapter also puts the horizontalist and structuralist analyses in a general theory of endogenous money. Building on the work of Hicks (1956 [1982]), Fontana interprets the horizontalist and structuralist analyses in light of an original time framework grounded on the distinction between a single-period analysis and a continuation analysis. A singleperiod analysis aims to disclose simple and stable relationships that may be precluded or difficult to disentangle, once all the complexities of the money-supply process are considered. For this reason, a single-period (horizontalist) analysis is based on the tacit assumption that within the period considered economic agents hold constant expectations. However, a limit of a single-period analysis is that it assumes the expectations of agents as given, and then explains the sequential stages of the moneysupply process. One of the features of the money-supply process, however, is the possibility of affecting the expectations of all agents involved in it. Therefore, the effects of changes in the state of expectations of central 
banks, commercial banks, firms, financial intermediaries and wage-earners are the main concern of a continuation (structuralist) analysis as argued by Fontana.

On the whole, the contributions presented in this book offer a wide and comprehensive understanding of the endogenous nature of money in both ancient and modern times, with a view to informing the current debate on the (expected) effectiveness of monetary policy interventions. Let us hope that the advances in endogenous-money analysis provided in this volume will inspire the relevant policy-makers, in order to design monetary policies better in line with the endogenous nature of money. This will also contribute to enhancing central banks' credibility and accountability, both of which are at stake as a result of the global financial crisis that erupted in 2008 and the ensuing unconventional interventions by the major central banks all over the world.

\section{NOTES}

1. Note that we prefer to refer to mainstream models as including 'endogenized money', as opposed to 'endogenous money' or 'money's endogeneity', precisely to emphasize the differences between orthodox and heterodox approaches to this matter.

2. A third distinction is offered by Rochon (1999), who argues that the mainstream approach to endogenized money is supply-determined. Lavoie (1996, p. 533) also claims that the mainstream 'view of endogeneity is different from that held by Post Keynesians or the circuitists. It is still based on a supply-determined stock of money, rather than a demand-determined one.'

3. Rochon and Setterfield $(2007,2008,2012)$ have proposed three post-Keynesian interestrate rules, where the interest rate is seen as a distributive variable, that is, what they have called the Smithin rule, the Kansas City rule and the Pasinetti rule, each with specific distributive implications.

\section{REFERENCES}

Chick, V. (1986), 'The evolution of the banking system and the theory of saving, investment and interest', Economies et Sociétés, 20 (8-9), 111-26. (Reprinted in P. Arestis and S.C. Dow (eds) (1992), On Money, Method and Keynes: Selected Essays of Victoria Chick, London and New York: Macmillan and St. Martin's Press, pp. 193-205.)

Deleplace, G. and E.J. Nell (eds) (1996), Money in Motion: The Post-Keynesian and Circulation Approaches, Basingstoke and New York: Macmillan and St. Martin's Press.

Eichner, A. (1987), The Macrodynamics of Advanced Market Economies, Armonk, NY, USA: M.E. Sharpe.

Fullwiler, S.T. (2003), 'Timeliness and the Fed's daily tactics', Journal of Economic Issues, 37 (4), 851-80. 
Graziani, A. (2003), The Monetary Theory of Production, Cambridge, UK: Cambridge University Press.

Hicks, J.R. (1956 [1982]), 'Methods of dynamic analysis', in Money, Interest and Wages: Collected Essays on Economic Theory, Vol. 2, Oxford: Basil Blackwell, pp. 217-35.

Kaldor, N. (1970), 'The new monetarism', Lloyds Bank Review, 97, 1-18. (Reprinted in N. Kaldor (1978), Further Essays in Applied Economics, London: Duckworth, pp. 1-21.)

Keynes, J.M. (1936), The General Theory of Employment, Interest and Money, London: Macmillan.

Lavoie, M. (1992), Foundations of Post-Keynesian Economic Analysis, Aldershot, UK and Brookfield, VT, USA: Edward Elgar.

Lavoie, M. (1996), 'Monetary policy in an economy with endogenous credit money', in G. Deleplace and E.J. Nell (eds), Money in Motion: The PostKeynesian and Circulation Approaches, Basingstoke and New York: Macmillan and St. Martin's Press, pp. 532-45.

Lavoie, M. (2006), 'A post-Keynesian amendment to the new consensus on monetary policy', Metroeconomica, 57 (2), 165-92.

Lavoie, M. (2014), Post-Keynesian Economics: New Foundations, Cheltenham, UK and Northampton, MA, USA: Edward Elgar.

Minsky, H.P. (1982), 'The financial instability hypothesis: an interpretation of Keynes and an alternative to "standard" theory', in H.P. Minsky, Can ' $I t$ ' Happen Again? Essays on Instability and Finance, Armonk, NY, USA: M.E. Sharpe, pp. 59-70.

Monvoisin, V. (2006), 'Les définitions post-Keynésiennes de la monnaie endogène: des divergences à la complémentarité', Economie Appliquée, 59 (4), 167-91.

Moore, B. (1979), 'Monetary factors', in A. Eichner (ed.), A Guide to Post Keynesian Economics, White Plains, NY, USA: M.E. Sharpe, pp. 120-38.

Moore, B.J. (1988), Horizontalists and Verticalists: The Macroeconomics of Credit Money, Cambridge, UK: Cambridge University Press.

Moore, B.J. (2001), 'Some reflections on endogenous money', in L.-P. Rochon and M. Vernengo (eds), Credit, Interest Rates and the Open Economy: Essays on Horizontalism, Cheltenham, UK and Northampton, MA, USA: Edward Elgar, pp. 11-30.

Niggle, C.J. (1991), 'The endogenous money supply theory: an institutionalist appraisal', Journal of Economic Issues, 25 (1), 137-51.

Palley, T.I. (1996), 'Accommodationism versus structuralism: time for an accommodation', Journal of Post Keynesian Economics, 18 (4), 585-94.

Palley, T.I. (2006), 'A post-Keynesian framework for monetary policy: why interest rate operating procedures are not enough', in C. Gnos and L.-P. Rochon (eds), Post-Keynesian Principles of Economic Policy, Cheltenham, UK and Northampton, MA, USA: Edward Elgar, pp. 78-98.

Palley, T. (2010), 'The politics of paying interest on bank reserves: a criticism of Bernanke's exit strategy', Challenge, 53 (3), 49-65.

Pollin, R. (1996), 'Money supply endogeneity: what are the questions and why do they matter?', in G. Deleplace and E.J. Nell (eds), Money in Motion: The Post Keynesian and Circulation Approaches, London and New York: Macmillan and St. Martin's Press, pp. 490-515.

Pollin, R. (2010), 'Austerity is not a solution: why the deficit hawks are wrong', Challenge, 53 (6), 6-36. 
Robinson, J. (1956), The Accumulation of Capital, London: Macmillan.

Robinson, J. (1962), 'Review of H.G. Johnson, Money, Trade and Economic Growth', Economic Journal, 72 (287), 690-92.

Rochon, L.-P. (1999), Credit, Money and Production: An Alternative Post-Keynesian Approach, Cheltenham, UK and Northampton, MA, USA: Edward Elgar.

Rochon, L.-P. (2012), 'Money's endogeneity, Keynes's General Theory and beyond', in T. Cate (ed.), Keynes's General Theory: Seventy-Five Years Later, Cheltenham, UK and Northampton, MA, USA: Edward Elgar, pp. 293-305.

Rochon, L.-P. (2016), 'In pursuit of the holy grail: monetary policy, the natural rate of interest, and quantitative easing', Studies in Political Economy, 97 (1), 87-94.

Rochon, L.-P. and S. Rossi (2013), 'Endogenous money: the evolutionary versus revolutionary views', Review of Keynesian Economics, 1 (2), 210-29.

Rochon, L.-P. and M. Setterfield (2007), 'Interest rates, income distribution and monetary policy dominance: Post Keynesians and the "fair" rate of interest', Journal of Post Keynesian Economics, 30 (1), 13-41.

Rochon, L.-P. and M. Setterfield (2008), 'The political economy of interest rate setting, inflation targeting and income distribution', International Journal of Political Economy, 37 (2), 5-25.

Rochon, L.-P. and M. Setterfield (2012), 'A Kaleckian model of growth and distribution with conflict-inflation and Post-Keynesian nominal interest rate rules', Journal of Post Keynesian Economics, 34 (3), 497-520.

Rogers, C. (1989), Money, Interest and Capital: A Study in the Foundations of Monetary Theory, Cambridge, UK: Cambridge University Press.

Rossi, S. (2001), Money and Inflation: A New Macroeconomic Analysis, Cheltenham, UK and Northampton, MA, USA: Edward Elgar.

Rossi, S. (2007), Money and Payments in Theory and Practice, London and New York: Routledge.

Smithin, J. (1994), Controversies in Monetary Economics: Ideas, Issues and Policy, Cheltenham, UK and Northampton, MA, USA: Edward Elgar.

Wicksell, K. (1898 [1965]), Interest and Prices: A Study of the Causes Regulating the Value of Money, New York: Augustus M. Kelley. 